\title{
THE PROFESSIONAL COMPETENCE OF TEACHERS IN INCLUSIVE PRACTICE AND THEIR ADVICE FOR PROSPECTIVE TEACHERS
}

\section{(D) Serdal DENİ ${ }^{1+}$ (D) Serife Senay İLIK ${ }^{2}$}

\author{
'Kayseri University, Faculty of Health Sciences, Department of Child \\ Development, Turkey. \\ Email:serdaldeniz1@gmail.com Tel: 00905071176527 \\ ${ }^{2}$ Necmettin Erbakan University, Ahmet Keleşoğlu Faculty of Education, \\ Department of Special Education, Turkey. \\ Email:senayilik@gmail.com Tel:00905065134709
}

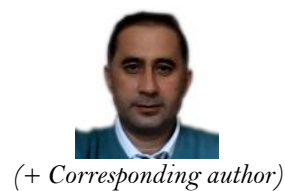

$(+$ Corresponding author $)$

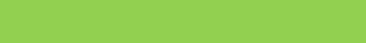

Article History

Received: 8 September 2021 Revised: 4 October 2021 Accepted: 27 October 2021 Published: 16 November 2021

\section{Keywords}

Inclusion

Branch teachers

Professional competence

Advice

Mixed method

Teacher candidates.

\section{ABSTRACT}

This research was carried out to identify teachers' professional competence development about inclusive practice and their advice for prospective teachers about this practice. Parallel Mixed-Methods Design was used in this study. In the quantitative research part of this study, "The Development of the Professional Competencies Scale' about Inclusion for teachers was used. Also, In the qualitative research part a Semi-Structured Interview Form was used to learn the recommendations of teachers who work in inclusive practices to prospective teachers about these practices. In this research, for data analysis in quantitative research part; percentage, frequency and arithmetic mean took part in descriptive statistics were used. Regarding the qualitative part, content analysis was implemented. As a result of this study, it was found out that teachers' professional development competencies related to inclusion were moderate, teachers' professional development competencies for inclusion didn't differ according to gender, teachers' getting education for inclusion was an important factor which determines teachers' professional development competencies for inclusion, and it has been determined that teachers' age, branches, the type of disability of their students are not important factors on their professional development competencies for inclusion. Teachers, about inclusion practices, teacher candidates; They provided advice on professional development, special education content information, arrangements for students, cooperation with staff, parent training, IEP training and integration adaptations.

Contribution/Originality: This study contributes to the existing literature in terms of revealing the professional competencies of teachers about inclusion practices. In addition, revealing the recommendations of the teachers about the inclusion practices in line with their professional experience will make the teacher candidates more professionally successful in the inclusion practices.

\section{INTRODUCTION}

Inclusion is special education implementations based on the principle that individuals with special educational needs continue their education and training together with their normally developing peers in state and private education institutions (MEB, 2017). The aim of inclusive education is to enable students with special needs to interact with students with normal development at all levels of education and to benefit from educational activities (MEB, 2017). Through inclusive education, students with special needs can maximize the integration of them into the society by improving their social development, self-care, language, and communication skills, as well as their academic activities (MEB, 2017). Sustainability of inclusive education in schools depends on many factors. 
Undoubtedly, the most important of these factors is teachers. Teachers are expected to be able to respond to the needs of children who have differences in their classes and to support the development of children of all levels and characteristics. For this reason, teachers need to have professional knowledge and skills related to inclusion, as well as their subject matter knowledge. Unless they have professional knowledge and skills related to inclusion, negative attitudes towards inclusive students can be seen in teachers. This situation also negatively affects the attitudes of normally developing students towards inclusive students (Akalin, Demir, Sucuoglu, Bakkaloglu, \& Iscen, 2014). In inclusive education, teachers should undertake many tasks such as knowing the principles of inclusive education, being able to apply these principles for inclusive students, recognizing the cognitive, emotional and physical characteristics of individuals with special needs, also identifying the needs of individuals with special needs, preparing an individualized education program (IEP), individualizing the program, and adapt it when necessary. In addition, with these educational arrangements, appropriate strategies should be used when negative behaviors are encountered (McGregor, Halverson, Fisher, Bhaermen, \& Salisbury, 1998).

However, it is inevitable for teachers who have completed their undergraduate education without gaining enough knowledge and experience to fulfill these duties, to encounter some problems when they start to work (Forlin \& Kuen-Fung, 2017). This situation reduces the quality of inclusive education and the negativities which teachers have experienced cause them to feel inadequate (Batu, 2010; McGregor et al., 1998). According to Metin (2018), most of the primary school teachers lack information about inclusive practices and relevant legislation and state that they need training on this subject. Unal and Saban (2017) state that only one out of ten teachers knows something about inclusive practices and most of them don't have any idea about how to follow inclusive education. In these researches, it has been found out that the educational practices whose aim are to ensure the professional development of teachers don't completely meet the needs. Accordingly, it is stated that many problems occur in inclusive education environments and that important steps should be taken to organize educational activities (Bagci \& Simsek, 2000; Taymaz, Sunay, \& Aytac, 1997). In their study, Yikmis and Bahar (2002) determined that the educators who work in the inclusive classroom needed professional support for setting goals, organizing instruction, preparing activities, ensuring classroom interaction, and preparing assessment tools. Sucuoglu and Akalin (2010) emphasized in their research that teachers couldn't make methods and techniques, classroom activities and adaptations to be used in the education of children with special needs. Teachers' deficiencies in managing the educational process affect their attitudes towards inclusion. Accordingly, it has been obtained by many studies that there is an important correlation between the self-efficacy and attitudes of teachers who work in inclusive classrooms (Akcamete, Kis, \& Gurgur, 2009; Altun \& Gulben, 2009; Batu, Odluyurt, Alagozoglu, Cattik, \& Sahin, 2017; Bozarslan \& Batu, 2014; Crane-Mitchel \& Hedge, 2007; Diken, 2006; Gok \& Erbas, 2011; Kale, Dikici Sigirtmac, \& Abbak, 2016; Kardes \& Taskin, 2020; Kiel, Braun, Muckenthaler, Heimlich, \& Weiss, 2019; Kucuk Dogaroglu \& S., 2015; Majoko, 2018; Sazak Pinar, 2014; Soodak \& Podell, 1993; Toy \& Duru, 2016; Tufan \& Yıldırım, 2013). In the scientific studies conducted from past to present, it has been stated that inclusive education has many benefits for both individuals with special needs and their peers with normal development in their classrooms. Thanks to inclusive education, students with special needs integrate with society and get new skills by modelling their peers. It has been found out that while the problems related to exclusion from the society are minimal (Farrell, 2000; Karagiannis, Stainback, \& Stainback, 1996), the positive effect on their affective development increases (Ahsan \& Sharma, 2018; Mulholland \& Cumming, 2016; Saloviita, 2020). In addition, thanks to inclusive education, while students with normal development learn to respect differences, social benefits come into prominence by developing cooperation and collaboration skills (Begeny \& Martens, 2007; Mastropieri \& Scruggs, 2004; Metin, 2018; Odom, 2000). When it is evaluated in terms of teachers, it is stated that professional skills develop as a result of teaching in inclusive classrooms (Begeny \& Martens, 2007; Karagiannis et al., 1996). Considering the benefits that students with special needs provide to students with normal development and teachers, and therefore to society, inclusive education is an education model that will indirectly improve respect for 
differences in society. With this study, it is aimed to determine the efficacy perceptions of teachers who take part in inclusive education and to reveal the advice they can give to prospective teachers in line with their feelings and thoughts. Therefore, it is thought that this study will shed light on future studies by determining problems and solutions in the light of data obtained from teachers and prospective teachers who interact with each other. This research was carried out in order to determine the professional competence development of teachers about inclusive practices and to determine their advice to prospective teachers about inclusive practices. For this purpose, answers were sought for the following sub-goals:

1-What are the professional competence development levels of teachers about inclusion?

2- Teachers' professional competence development levels related to inclusion

Does it differ according to...

a. their gender,

b. Status of getting education about inclusion,

c. Age,

d. Branch,

e. Type of student disability, and

f. the years of professional seniority?

3- About the inclusive practices of teachers to prospective teachers:

What are their advice for.

a- classroom applications

b- Supporting the social development of inclusive students,

c- Parents

d- IEP

e- Normally developing students?

\section{METHOD}

The research was carried out with mixed method consisting of an integration of quantitative and qualitative techniques.

Mixed method is defined as conclusions from the data as a result of the combination of data which is obtained with qualitative and quantitative methods (Cresswell, 2013). In this study, the parallel model, one of the mixed research models, was used. In parallel model research, there are two series of research, one of which seeks answers to quantitative research questions and the other to qualitative research questions and is usually carried out simultaneously and independently from each other (Greene, 2007; Mertkan, 2015).

\subsection{Participants}

The research was carried out in the fall of 2019. Ninety-five teachers and ninety-five prospective teachers from Konya participated in the research. The research was carried out in eighteen schools located in Konya, with English, Social Studies, Turkish, Mathematics and Primary School teachers who have inclusive students and prospective teachers who study in English, Social Studies, Turkish, Mathematics and Primary School Teaching departments. Prospective teachers were preferred by the researchers because they took special education and inclusive lessons. The prospective teachers who participated in the research did their internship at different levels of schools for a total of 12 weeks and 6 hours in a week due to their teaching practice courses. 95 prospective teachers from different branches participated in the study, and the prospective teachers interviewed 95 teachers from their own branch during their teaching practice internships. The demographic characteristics of the teachers who participated in the research through prospective teachers are given in Table 1. 
Table-1. Demographic information of teachers participating in the research.

\begin{tabular}{|c|c|c|c|}
\hline Variables & Values & $\mathbf{N}$ & $\%$ \\
\hline \multirow[t]{2}{*}{ Gender } & Female & 67 & 70,5 \\
\hline & Male & 28 & 29,5 \\
\hline \multirow[t]{4}{*}{ Age } & 23-30 years & 25 & 26,3 \\
\hline & $31-38$ years & 39 & 41,1 \\
\hline & $39-46$ years & 22 & 23,2 \\
\hline & $47-54$ years & 9 & 9,5 \\
\hline \multirow[t]{5}{*}{ Branch } & English & 30 & 31,6 \\
\hline & Turkish & 17 & 17,9 \\
\hline & Social Studies & 17 & 17,9 \\
\hline & Mathematics & 13 & 13,7 \\
\hline & Primary School Teaching & 18 & 18,9 \\
\hline \multirow[t]{2}{*}{ Inclusive practices Education Status } & Yes & 42 & 44,2 \\
\hline & No & 53 & 55,8 \\
\hline \multirow[t]{6}{*}{ The inadequacy of the students in their classes } & Learning Disability & 19 & 20,0 \\
\hline & Mental Deficiency & 33 & 34,7 \\
\hline & ADHD & 10 & 10,5 \\
\hline & Physical Deficiency & 10 & 10,5 \\
\hline & Autism & 14 & 14,7 \\
\hline & Visual and Hearing disability & 9 & 9,5 \\
\hline \multirow[t]{5}{*}{ Professional Seniority } & $1-5$ year & 20 & 21,1 \\
\hline & $6-10$ year & 16 & 16,8 \\
\hline & $11-15$ year & 28 & 29,5 \\
\hline & $15-20$ year & 19 & 20,0 \\
\hline & 20 year and over & 12 & 12,6 \\
\hline Total & & 95 & 100 \\
\hline
\end{tabular}

When Table 1 is examined, a total of 95 teachers from English, Turkish, Mathematics, Social Studies and Primary School Teaching branches participated in the study, 67 of whom were female and 28 were male. The ages of the teachers range from 23 to 54. Their Professional seniority, on the other hand, varies. It is seen that 42 of the teachers received training on inclusive practices and 53 teachers didn't receive any training. It is seen that the teachers participating in the research have students with Learning Disability, Mental Deficiency, ADHD, Physical Deficiency, Autism, Visual and Hearing disabilities in their classes.

Table-2. Demographic Information of Prospective Teachers participating in the research.

\begin{tabular}{l|l|c|c}
\hline Variables & Values & $\mathbf{N}$ & \% \\
\hline \multirow{4}{*}{ Gender } & Female & 53 & 55.8 \\
\cline { 2 - 4 } & Male & 42 & 44.2 \\
\hline \multirow{4}{*}{ Age } & 21 & 15 & 15.8 \\
\cline { 2 - 4 } & 22 & 40 & 42.1 \\
\cline { 2 - 4 } & 23 & 20 & 21.05 \\
\cline { 2 - 4 } & 24 and over & 20 & 21.05 \\
\hline \multirow{5}{*}{ Branch } & English & 30 & 31.6 \\
\cline { 2 - 4 } & Turkish & 17 & 17.9 \\
\cline { 2 - 4 } & Social Studies & 17 & 17.9 \\
\cline { 2 - 4 } & Mathematics & 18 & 13.7 \\
\cline { 2 - 4 } & Primary School Teaching & 95 & 18.9 \\
\hline \multirow{2}{*}{ Total } & & 100 \\
\hline
\end{tabular}

When Table 2 is examined, 53 of the prospective teachers participating in the research are female and 42 are male. The branches of the participants aged 21 and over consist of English, Turkish, Mathematics, Social Studies and Primary School Teaching departments. 


\subsection{Data Collection Tools}

In the quantitative phase of the research, the 'Development of the Professional Competency Scale About Inclusion for Teachers' developed by Karaca (2018) was used. There are 38 items in the scale. The scale has 1 (Strongly Agree), 2 (Agree), 3 (Partly Agree), 4 (Disagree), and 5 (Strongly Disagree) items. The scale consists of two parts. In the first part, questions about personal information were included, and in the second part, the "The Development of the Professional Competency Scale for Inclusion", which was prepared to determine teachers' professional competencies related to inclusion, was included. The scale consists of 38 questions including seven subdimensions. Response time for the scale varies between 7-12 minutes. In the validity and reliability studies of the scale, the general Cronbach Alpha reliability coefficient is .97,7.

In the qualitative techniques phase of the research, the semi-structured interview form which was developed by researchers "Advice of the Branch Teachers Working in Inclusive Practices for Prospective Teachers about Inclusive Practices" was used. In the preparation of the interview forms, we should pay attention to the fact that the questions which are directed to the participants are easy and understandable, they are subject-oriented questions, they are open-ended questions, there is no direction in the questions and interviews, and the questions are prepared in a logical way (Yildirim \& Simsek, 2006). The researchers adhered to the literature in the preparation of the semistructured interview form and the forming of the questions. In the semi-structured interview form, there are some demographic information about the gender of the participants, the institution they work in, their branch, the diagnoses of the inclusive students they encounter, training, seminars and etc. about inclusive practices. In the forming of Semi-Structured Interview form questions, the researchers first prepared a draft interview form. Opinions of two special education experts and two assessment and evaluation experts were sought regarding the prepared interview form questions. A pilot study was conducted with three different branch teachers in order to check the clarity of the questions, whether they were subject-oriented or not, and whether the questions were related to the research in a logical way. After the pilot study, the researchers examined the interview forms together and by making the necessary corrections in the questions, the following questions and sub-questions were added to the semi-structured interview form in their final form. After the interview form was prepared, questions were asked by the prospective teachers to their teachers in internship applications.

1- What is your advice for inclusive practices in classroom?

A- Do you have problems with what to do when you suspect the inability of the student you teach in the classroom, what do you need in this process?

B- Do you make any differences in courses and in exams for an inclusive student, how? What suggestions do you give me?

C- Do you need material, method, technique or any resource arrangement in the course for the inclusive student? What suggestions do you give me?

2- What is your advice for social development of students in inclusive practices?

A- Do you take any precautions for the socialization of the student?

B- Do you know any problem with the socialization of the student? What suggestions can you give me?

3- What is your advice for the families of inclusive students?

A- Do you cooperate with families? How?

B- What problems do you have with families? What suggestions do you make to solve these problems?

4- What is your advice for Individualized Education Programs (IEP) prepared for inclusive students?

A- Are you involved in the IEP process? Do you have any trouble with this situation, how?

B- Do you have problems during the implementation of the IEP? What suggestions do you give me?

C- Do you have problems during the IEP evaluation process? What suggestions do you give me?

5- What is your advice for students with normal development in inclusive practices?

A- What can I do about the families of normally developing students? 
B- What can I do for normally developing students?

\subsection{Data Collection}

During the data collection process, first of all, the research was explained to the prospective teachers and they were asked whether they would like to participate voluntarily. A total of one hundred and six prospective teachers from five different branches who agreed to participate in the research were divided into groups according to their branches and information was given by the researchers about how the research would be conducted for two weeks and thirty minutes. At the end of two weeks, all the one hundred and six prospective teachers who they were asked again whether they would like to participate in the research voluntarily or not stated that they would like to participate voluntarily again. After the research process started and eight prospective teachers decided to fill in the scale and their advice for inclusive practices would not be sufficient, the eight prospective teachers left the research process with decision of researchers and prospective teachers together. During the data collection process, the researchers made some explanation to ninety-eight prospective teachers about how to fill in the scale and interview form in the third week meeting. In the explanations, it was stated that the scale lasts approximately 7-12 minutes and that the internship teachers working in inclusive practices will fill in it themselves. In the explanations which were made to the prospective teachers about how to fill in the semi-structured interview forms, it was explained that the prospective teachers should fill in the questions in the form of a mutual conversation with the internship teachers in a quiet environment without time limit. In addition, it was stated that the interviews should be impartial and that the answers to the questions given by the teachers should be noted as they are. Additionally, it was explained that the prospective teachers who conducted the interview should give feedback on the answers they gave to the teachers they interviewed, and that they should receive participant confirmation when the interview was over whether there was a section they wanted to add, remove or change or not. After the meetings and explanations, a total of ninety-eight 'Professional Competency Development Scales Related to Inclusion for Teachers' and ninetyeight 'Advice of Branch Teachers Working in Inclusive Practices for Prospective Teachers about Inclusive Practices' semi-structured interview forms were received from the prospective teachers a week later.

\subsection{Data Analysis}

The 'Professional Competence Development scale related to Inclusion for teachers' filled out by teachers was analysed using the SPSS 21 package program. Before the data were analysed, data analyses were checked. Three invalid data were excluded from the research due to some reasons such as missing, condensation in the same option, and finally, the data of 95 participants were analysed. In the analysis of the data, percentage, frequency, and arithmetic mean from descriptive statistics were used. In addition, while unpaired t-test was applied to determine the difference according to gender and inclusive education in line with sub goals, Kruskal Wallis test was applied to determine the difference according to age, branch, disability status and professional seniority. The Kruskal Wallis test was used because it didn't meet the parametric conditions. The competencies of the teachers in the interpretation of the data were evaluated as low, medium, and high. In this context, the average scores were evaluated using the formula (highest score - lowest score)/the number of criteria, i.e. (5-1)/3. In this context, 1.002.33 was evaluated as low, 2.34-3.66 was evaluated as medium, and 3.67-5.00 was evaluated as high competence. The semi-structured interview form 'Advice of Teachers Working in Inclusive Practices for Prospective Teachers about Inclusive Practices', conducted by the prospective teachers with their teachers in internship practices, was analysed by content analysis, which is one of the qualitative methods. In the content analysis, a framework for data analysis based on the research questions and the dimensions in the interview was created. Accordingly, first of all, the obtained data were conceptualized, the emergent concepts were arranged in a logical way and the themes which explain the data were determined. In the examination of the interview form, the researchers created a key code next to each item. The key code was first created independently by the researchers, then they finalized it by coming 
together. The data were marked independently by the researchers on the key code. According to the key code and the data obtained from the interviews, the codes were sometimes made for a sentence and sometimes for a word. Then, the coding was compared and for the reliability of the research, the average reliability for all questions was calculated as $83 \%$ by using Consensus/ Consensus + Dissensus Formula. The researchers decided together that three teachers gave superficial answers in the interviews, and because they didn't find it appropriate to analyze these interview forms, they were excluded from the research process. In the data analysis of the interview forms, the content analysis of the data was made, and some codes were determined, the categories from the codes and the themes from the categories were reached. The coding was made according to the type of coding made by the researchers in a general framework. The reason for choosing this coding type is that it is possible to create a general conceptual structure before the analysis of the data. After the data obtained from the interview forms was coded, the common aspects between the codes were tried to be found and the codes were combined, and they created the categories. The categories obtained in the research were also combined and more general themes were formed and presented in the findings section.

\section{FINDINGS}

The Professional Competence Development of Teachers about Inclusion and teachers' advice for prospective teachers are included in this section. The professional development competence levels of the teachers participating in the research about inclusion are given in Table 3.

Table-3. Teachers' Professional Development Competence Levels About Inclusion (n=95).

\begin{tabular}{l|c|c}
\hline Factors & $\overline{\mathbf{x}}$ & Ss \\
\hline Teaching methods and techniques & 3.57 & 0.679 \\
\hline Individualized education program & 3.60 & 0.823 \\
\hline Diagnosis and evaluation & 3.26 & 0.801 \\
\hline Duties and responsibilities & 3.69 & 0.762 \\
\hline Material development & 3.55 & 0.830 \\
\hline Parent education/cooperation & 3.33 & 0.866 \\
\hline Legal regulations & 3.28 & 0.992 \\
\hline Average Scale Score & 3.47 & 0.655 \\
\hline
\end{tabular}

When Table 3 is examined, the professional development competence level of teachers about inclusion was found as medium (=3.47).

Similarly, it was seen that teachers had medium level of competence in the sub-dimensions of teaching methods and techniques $(\mathrm{X}=3.57)$, individualized education program $(\mathrm{X}=3.60)$, diagnosis and evaluation $(\mathrm{X}=3.26)$, material and development $(\mathrm{X}=3.55)$, parent education and cooperation $(\mathrm{X}=3.33)$, and legal regulations $(\mathrm{X}=3.28)$ but they had high level of competence only for sub-dimensions of duties and responsibilities $(\mathrm{X}=3.69)$.

In the study, the professional development competencies of teachers about inclusion according to their gender are shown in Table 4.

Table-4. Teachers' professional development competencies about inclusion according to their gender.

\begin{tabular}{c|c|c|c|c|c|c}
\hline Gender & $\mathbf{N}$ & $\overline{\mathrm{X}}$ & $\mathbf{S s}$ & $\mathbf{s d}$ & $\mathbf{T}$ & $\mathbf{p}$ \\
\hline Female & 67 & 3.51 & 0.626 & 93 & 1.044 & 0.299 \\
\hline Male & 28 & 3.36 & 0.719 & & & \\
\hline
\end{tabular}

When Table 4 is examined, it can be seen that the professional development competencies of teachers about inclusion don't differ according to their genders $[\mathrm{t}(93)=1.044, \mathrm{p}>.05]$. The difference between the average 
competence scores of female teachers $(\mathrm{X}=3.51)$ and average competence scores of male teachers related to inclusion $(\mathrm{X}=3.26)$ is not statistically significant.

The professional development competencies related to inclusion according to the teachers' inclusive education status are shown in Table 5.

Table-5. Teachers' professional development competencies related to inclusion according to their inclusive education status.

\begin{tabular}{l|c|c|c|c|c|c}
\hline Education Status & $\mathbf{N}$ & $\overline{\mathrm{X}}$ & $\mathbf{S s}$ & $\mathbf{s d}$ & $\mathbf{T}$ & $\mathbf{p}$ \\
\hline I had & 42 & 3.74 & 0.608 & 93 & 3.912 & $0.001^{*}$ \\
\hline I didn't have & 53 & 3.25 & 0.611 & & & \\
\hline Note: ${ }^{\mathrm{p}<.05 .}$
\end{tabular}

When Table 5 is examined, it can be seen that teachers' competencies related to inclusion differ according to their education status about inclusion $[\mathrm{t}(93)=3.912, \mathrm{p}<.05]$. The competence scores of the teachers who received training $(\mathrm{X}=3.74)$ differ significantly from the competence scores of the teachers who didn't receive training $(\mathrm{X}=3.25)$.

Professional Development Competencies of Teachers about Inclusion according to their Age are shown in Table 6.

Table-6. Kruskal Wallis-H test results of teachers' professional development competencies related to inclusion according to their age.

\begin{tabular}{|c|c|c|c|c|c|}
\hline Age Ranges & $\mathbf{N}$ & Rank Average & Sd & $\chi^{2}$ & $\mathbf{p}$ \\
\hline $23-30$ & 25 & 48.64 & \multirow[t]{4}{*}{3} & \multirow[t]{4}{*}{4.016} & \multirow[t]{4}{*}{0.260} \\
\hline $31-38$ & 39 & 53.50 & & & \\
\hline $39-46$ & 22 & 41.95 & & & \\
\hline $47-54$ & 9 & 37.17 & & & \\
\hline
\end{tabular}

As it can be seen from Table 6, the professional development competencies of teachers about inclusion don't differ significantly according to their ages $\left[\chi^{2}\right.$ [3-4.016], p>.05].The age ranges of teachers don't cause any difference in their professional development competencies related to inclusion.

Professional Development Competencies of Teachers About Inclusion According to Their Branches are given in Table 7.

Table-7. Kruskal Wallis-H test results of teachers' professional development competencies related to inclusion according to their branches.

\begin{tabular}{c|c|c|c|c|c}
\hline Branch & N & Rank Average & Sd & $\boldsymbol{\chi}^{2}$ & p \\
\hline English & 30 & 50.48 & \multirow{2}{*}{2.114} & 0.715 \\
\hline Turkish & 17 & 54.18 & & \\
\cline { 1 - 3 } Social Studies & 17 & 46.15 & & \\
\cline { 1 - 3 } Mathematics & 13 & 42.65 & & \\
\hline
\end{tabular}

It is seen in Table 7 that the branches of the teachers didn't cause any significant difference on their professional development competencies related to inclusion $\left[\chi^{2}\right.$ [4-2.114], p>.05]. Teachers' professional development competencies related to inclusion don't differ according to their branches.

The Professional Development Competencies of Teachers about Inclusion According to the Disability Type of the Students are shown in Table 8.

When Table 8 is examined, it can be said that the professional development competencies of teachers about inclusion don't differ according to the disability types in their classrooms $\left[\chi^{2}[5-6.288], \mathrm{p}>.05\right]$. It can be stated that teachers' professional development competencies related to inclusion are at the same level, regardless of their students' disability types. 
Table-8. Kruskal Wallis-H test results of teachers' professional development competencies related to inclusion according to the students' disability type.

\begin{tabular}{l|c|c|c|c|c}
\hline Disability Type & N & Rank Average & Sd & $\boldsymbol{\chi}^{\mathbf{2}}$ & p \\
\hline Learning Disability & 19 & 38.18 & \multirow{2}{*}{5} & 6.288 & 0.279 \\
Mental Deficiency & 33 & 54.61 & & & \\
\cline { 1 - 3 } ADHD & 10 & 38.40 & & & \\
\cline { 1 - 3 } Physical deficiency & 10 & 50.00 & & & \\
\cline { 1 - 3 } Autismal and Hearing disability & 14 & 46.36 & & & \\
\cline { 1 - 3 }
\end{tabular}

Teachers' Professional Development Competencies Related to Inclusion according to Their Seniority Years are given in Table 9.

Table-9. Kruskal Wallis-H test results of professional development competencies related to inclusion according to the seniority years.

\begin{tabular}{c|c|c|c|c|c}
\hline Seniority Years & $\mathbf{N}$ & Rank Average & Sd & $\boldsymbol{\chi}^{\mathbf{2}}$ & $\mathbf{p}$ \\
\hline 1-5 year & 20 & \multirow{2}{*}{39.08} & \multirow{2}{*}{9.359} & \multirow{2}{*}{0.053} \\
\hline 6-10 year & 16 & 63.00 & & & \\
11-15 year & 28 & 52.71 & & & \\
\hline 15-20 year & 19 & 43.08 & & \\
\hline
\end{tabular}

When Table 9 is examined, it can be said that the professional development competencies of teachers about inclusion don't differ according to their years of seniority [ $\chi^{2}$ [4-9.359], p>.05]. It can be said that the seniority years of the teachers doesn't cause any difference in their professional development competencies for inclusion.

The advice of teachers for prospective teachers about their classroom practices are given in Table 10.

When Table 10 is examined, it is seen that advice of teachers for prospective teachers about their classroom practices are gathered in forty-one codes.

Five categories were obtained from forty-one codes and two themes were obtained from the categories.

It can be said that the advice given by the teachers for the prospective teachers about their classroom practices is related to the acquisition of professional development and special education content knowledge.

The advice of teachers for the prospective teachers about supporting the social development of the inclusive students are given in Table 11.

When Table 11 is examined, it is seen that the advice of teachers for prospective teachers about supporting the social development of inclusive students are gathered in twenty-three codes.

Four categories were obtained from twenty-three codes and two themes were obtained from the categories.

It can be said that the advice of teachers for prospective teachers about supporting the social development of the inclusive students are related to the arrangements for the students and cooperation with staff.

The advice of teachers for prospective teachers about the parents of inclusive students are given in Table 12 .

When Table 12 is examined, it is seen that the advice of teachers for the prospective teachers about the parents of the inclusive students are gathered in twenty-five codes. Two categories were obtained from twenty-five codes and a theme was obtained from the categories. It can be said that the advice of teachers for prospective teachers about the parents of the inclusive students are related to parent education.

The advice of teachers for the prospective teachers about IEP are given in Table 13.

When Table 13 is examined, it is seen that teachers' advice for prospective teachers about IEP are gathered in eleven codes. Three categories were obtained from the eleven codes and a theme was obtained from the categories. It can be said that the advice of teachers about IEP for prospective teachers are related to the necessity of receiving IEP training. 
The advice of teachers for prospective teachers about the students with normal development in inclusive practices are given in Table 14.

Table-10. Advice of teachers for prospective teachers about classroom practices

\begin{tabular}{|c|c|c|}
\hline Code & Category & Theme \\
\hline $\begin{array}{l}\text { They should establish Positive communication and cooperation } \\
\text { with the parents of inclusive students and students with normal } \\
\text { development. } \\
\text { They should cooperate with experts, school administration, school } \\
\text { counselling service and other teachers for inclusive students. } \\
\text { They should cooperate with normally developing students. }\end{array}$ & Cooperation & \multirow[t]{2}{*}{$\begin{array}{l}\text { Professional } \\
\text { Development }\end{array}$} \\
\hline $\begin{array}{l}\text { They should be informed of behavior modification techniques. } \\
\text { They should be informed of development of inclusive students. } \\
\text { They should get training and seminars about special education. } \\
\text { They should follow journals, books, articles and internet resources } \\
\text { related to students with special needs. }\end{array}$ & Education & \\
\hline $\begin{array}{l}\text { They should do socialization activities in the classroom. } \\
\text { They should involve them in group games/activities with their } \\
\text { peers. } \\
\text { They should try to make inclusive students love the school, their } \\
\text { teachers and their classmates. } \\
\text { They should place inclusive students in the front rows. } \\
\text { They should remove stimuli that can distract in class. } \\
\text { They should often try to get their attention } \\
\text { in class. } \\
\text { They should offer individual support training as well as inclusive } \\
\text { practices. } \\
\text { They should give short and simple homework. } \\
\text { They should be patient and calm. } \\
\text { They should treat students with respect. They should make } \\
\text { frequent eye contact in class. } \\
\text { They should always communicate with students. } \\
\text { They should give some clues in lessons and activities. } \\
\text { They should create a positive classroom climate. } \\
\text { They should provide peer support. } \\
\text { They should support the motivation and self-confidence of inclusive } \\
\text { students. } \\
\text { They should use reinforcement for inclusive students. } \\
\text { They should use simple, plain expressions in lessons. } \\
\text { They should give some classroom responsibilities to inclusive } \\
\text { students. } \\
\text { They should organize activities suitable for the level of inclusive } \\
\text { students. } \\
\text { They should use teaching methods and techniques according to the } \\
\text { interests and needs of inclusive students, their level of readiness and } \\
\text { the type of disability. } \\
\text { They should provide education in accordance with the IEP of the } \\
\text { inclusive students. }\end{array}$ & $\begin{array}{l}\text { Classroom } \\
\text { adaptations }\end{array}$ & \multirow[t]{3}{*}{$\begin{array}{l}\text { Special } \\
\text { education } \\
\text { content } \\
\text { knowledge }\end{array}$} \\
\hline $\begin{array}{l}\text { They should prepare questions suitable for their level in the exams. } \\
\text { They should give extra time to inclusion students in } \\
\text { exams/activities. }\end{array}$ & $\begin{array}{l}\text { Exam } \\
\text { adaptations }\end{array}$ & \\
\hline $\begin{array}{l}\text { They should offer rich material support to inclusive students. } \\
\text { They should provide visual and auditory material support to } \\
\text { inclusive students. } \\
\text { They should use resources suitable for the level of inclusive } \\
\text { students. }\end{array}$ & $\begin{array}{l}\text { Material } \\
\text { adaptations }\end{array}$ & \\
\hline
\end{tabular}


Table-11. Teachers' advice for prospective teachers about supporting the social development of inclusive students.

\begin{tabular}{|c|c|c|}
\hline Code & Category & Theme \\
\hline $\begin{array}{l}\text { Inclusive students should be supported in areas where they are } \\
\text { good. } \\
\text { Positive behaviours should be reinforced. } \\
\text { It should be given the opportunity to speak frequently in the } \\
\text { lessons. } \\
\text { Tasks and activities suitable for their level should be given. } \\
\text { We should ask the inclusive students' help with the activities } \\
\text { you think they can do. }\end{array}$ & $\begin{array}{l}\text { Classroom } \\
\text { interaction }\end{array}$ & \multirow[t]{3}{*}{$\begin{array}{l}\text { Regulations } \\
\text { for students }\end{array}$} \\
\hline $\begin{array}{l}\text { The inclusive student should be seated in the same row with a } \\
\text { sociable peer. } \\
\text { Normally developing peers should be encouraged to 'peer } \\
\text { coaching'. } \\
\text { Joint working group should be organized with peers with } \\
\text { normal development. } \\
\text { Normally developing students should be encouraged to spend } \\
\text { their time with inclusive students. } \\
\text { They should give homework and make explanations for the } \\
\text { students with normal development about some values such as } \\
\text { friendship, helpfulness, and respect. }\end{array}$ & $\begin{array}{l}\text { Peer } \\
\text { education }\end{array}$ & \\
\hline $\begin{array}{l}\text { You should also chat with the inclusive student outside of the } \\
\text { classroom. } \\
\text { You should support the inclusive students in solving the } \\
\text { problems faced by them. } \\
\text { Trips, games, activities, projects, assignments, and club } \\
\text { activities should be organized in which normally developing } \\
\text { peers and inclusive students can participate together. } \\
\text { Home visits should be made to the homes of inclusive students. }\end{array}$ & $\begin{array}{l}\text { Out-of-class } \\
\text { interaction }\end{array}$ & \\
\hline $\begin{array}{l}\text { Peers with normal development should be informed about the } \\
\text { inclusive student. } \\
\text { Information about the importance of inclusion should be given } \\
\text { to the parents of inclusive students, the parents of their peers } \\
\text { with normal development, school administration, teachers, and } \\
\text { other staff at the school. } \\
\text { Cooperation with families should be established (for the } \\
\text { inclusive student to establish friendship with their peers in and } \\
\text { out of school) } \\
\text { If necessary, information should be obtained from the school } \\
\text { counselling service. }\end{array}$ & $\begin{array}{l}\text { Cooperation } \\
\text { and } \\
\text { instruction }\end{array}$ & $\begin{array}{l}\text { Cooperation } \\
\text { with staff }\end{array}$ \\
\hline
\end{tabular}

Table-12. Teachers' advice for prospective teachers about parents

\begin{tabular}{|c|c|c|}
\hline Code & Category & Theme \\
\hline $\begin{array}{l}\text { Family expectations should be considered. } \\
\text { Families should be given positive information about their children. } \\
\text { Families should be explained that they should respect and value their } \\
\text { children. } \\
\text { It should be explained to parents that they need to communicate with } \\
\text { people they are happy with. } \\
\text { The importance of family support in the acquisition of classroom and } \\
\text { school rules should be explained. } \\
\text { Parents should be informed about the difficulties experienced by the } \\
\text { inclusive student in lessons. } \\
\text { The importance of cooperation in the student's homework should be } \\
\text { explained. } \\
\text { It should be explained that family support is important in ensuring the } \\
\text { permanence and generalization of the knowledge and skills gained in the } \\
\text { classroom. } \\
\text { It should be explained that absenteeism in school will negatively affect } \\
\text { the student. }\end{array}$ & $\begin{array}{l}\text { Informing } \\
\text { the parents }\end{array}$ & $\begin{array}{l}\text { Parent } \\
\text { education }\end{array}$ \\
\hline
\end{tabular}




\begin{tabular}{|c|c|}
\hline $\begin{array}{l}\text { Parents should be told that inclusive students should work together to } \\
\text { solve their problem behaviors. } \\
\text { Parents should be told that positive behaviors at home will affect their } \\
\text { classroom environment. } \\
\text { Parents should be encouraged to follow books, articles, magazines, and } \\
\text { websites about their children with special needs. }\end{array}$ & \\
\hline $\begin{array}{l}\text { Support groups should be established among the parents of inclusive } \\
\text { students. } \\
\text { The active participation of family in education of the child should be } \\
\text { ensured. } \\
\text { Joint activities should be organized with all parents and students. } \\
\text { Parents should be encouraged to participate in social activities with their } \\
\text { children. } \\
\text { The areas where they will take responsibility in the education of their } \\
\text { children should be taught. } \\
\text { Teaching methods and techniques related to meeting the needs of their } \\
\text { children should be provided. } \\
\text { Parents' participation in the preparation, development, implementation, } \\
\text { and evaluation stages of IEP should be ensured. }\end{array}$ & $\begin{array}{l}\text { Enabling } \\
\text { parents }\end{array}$ \\
\hline
\end{tabular}

Table-13. Teachers' advice for prospective teachers about IEP.

\begin{tabular}{|c|c|c|}
\hline Code & Category & Theme \\
\hline $\begin{array}{l}\text { Before preparing IEP, the student should be evaluated in detail. } \\
\text { The goals set in the IEP should be suitable for the student's } \\
\text { performance level. } \\
\text { Expert support should be received in the realization of the goals of IEP. } \\
\text { Precautions should be taken against the difficulties of IEP applications } \\
\text { in crowded classrooms. } \\
\text { Essentially, Problem behaviors that make difficult to implement IEP } \\
\text { goals should be removed. }\end{array}$ & $\begin{array}{l}\text { Preparation of } \\
\text { IEP }\end{array}$ & $\begin{array}{l}\text { IEP } \\
\text { education }\end{array}$ \\
\hline $\begin{array}{l}\text { We should be in constant communication with family during the } \\
\text { development of IEP. } \\
\text { The goals in the IEP should be able to be changed according to the } \\
\text { progress of the student. } \\
\text { Material preparations should be made according to the goals in the IEP. } \\
\text { Among the goals of the IEP, there should also be goals for the } \\
\text { socialization of the inclusive student with their peers. } \\
\text { Training about IEP preparation, development, implementation, and } \\
\text { evaluation should be taken. } \\
\text { While determining the goals of the IEP, the opinions of the inclusive } \\
\text { student should be consulted. }\end{array}$ & $\begin{array}{l}\text { Implementation } \\
\text { of IEP }\end{array}$ & \\
\hline $\begin{array}{l}\text { Student progress should be monitored. } \\
\text { Student progress should be evaluated. }\end{array}$ & $\begin{array}{l}\text { Evaluation } \\
\text { IEP }\end{array}$ & \\
\hline
\end{tabular}

Table-14. Teachers' advice for prospective teachers regarding students showing normal development in inclusive practices.

\begin{tabular}{l|l|l}
\hline Code & Category & Theme \\
\hline Information about inclusive practices and inclusive students should & Informing \\
be given. & $\begin{array}{l}\text { Integration } \\
\text { adaptations }\end{array}$ \\
Information should be given that they are important for the success \\
of inclusive practices. \\
Information about the importance of cooperation in inclusive \\
practices should be given. \\
Peer teaching and its importance should be explained. \\
Inclusive students should be observed by students with normal \\
development. & \\
\hline It should be explained to the parents of normally developing \\
students that their children are important in inclusive practices and \\
that they also have duties and responsibilities. \\
Teachers should be a model for students in inclusive practices. \\
\hline
\end{tabular}




\begin{tabular}{l|l|l}
\hline $\begin{array}{l}\text { Projects, events, and competitions regarding inclusive practices } \\
\text { should be organized. }\end{array}$ & $\begin{array}{l}\text { Including joint } \\
\text { events }\end{array}$ \\
Joint works should be organized. & \\
Students with normal development should also be included in the \\
solution of problems that happen in inclusive practices. \\
Studies should be carried out on values such as cooperation, \\
sharing, empathy, respect, and love. \\
Normally developing students should be taught to live together \\
and democratic understanding.
\end{tabular}

When Table 14 is examined, it is seen that the advice of the teachers about the students with normal development in inclusive practices are gathered in twelve codes. Three categories were obtained from twelve codes and one theme was obtained from the categories. It can be said that the advice of the teachers about the students showing normal development in the inclusive practices are related to the integration adaptations.

\section{DISCUSSION AND COMMENTS}

In this section, the inclusion proficiency scale applied to teachers is examined and discussed in terms of various demographic characteristics. In addition, the advice of teachers for prospective teachers regarding the inclusive students were also discussed.

According to the findings of our study and the results of the inclusion self-efficacy scale applied to the branch teachers working in inclusive environments, the professional development competencies of the teachers about inclusion are at a moderate level. In addition, while the professional development competencies of teachers in terms of duties and responsibilities are found to be high-level qualifications, in all dimensions of teaching methods and techniques, individualized education program, diagnosis and evaluation, material development, parent education and cooperation, and legal regulations, teachers have an intermediate level of competence. It is known that teachers' self-efficacy perceptions affect their attitudes towards inclusion (Kiel et al., 2019). Therefore, teachers with low sense of self-efficacy approach the inclusive process with anxiety (Soodak \& Podell, 1993). Teachers with high sense of self-efficacy display more constructive attitude towards the inclusive student in their class (Kaner, 2010). When the studies in the field are examined, it is possible to come across many studies aimed at determining self-efficacy for inclusion. Among these studies, Toy and Duru (2016) and Yavuz (2018) found out that prospective teachers or teachers in different branches have high self-efficacy perceptions. Dolapci (2013) and Vural Batik and Firinci Kodaz (2018) obtained results in the medium level in their studies. Camadan (2012) examined the self-efficacy perceptions of primary school teachers and prospective primary school teachers towards inclusive education and found that prospective teachers have higher self-efficacy than teachers. Sari, Celikoz, and Seçer (2009) in their study on preschool teachers' and prospective teachers' self-efficacy about inclusion, found out that, unlike Camadan (2012), teachers have higher self-efficacy than prospective teachers. In a similar study, it was concluded that teachers' selfefficacy in meeting the needs of inclusive students was low (Forlin \& Kuen-Fung, 2017). Battal (2007) on the other hand, in his study in which he examined the competencies of primary school teachers and branch teachers for inclusive education; It has been concluded that while teachers find themselves inadequate in terms of legislation and principles, they find themselves sufficient in recognizing, including students in education and evaluating them. Chao, Forlin, and Ho (2016) conducted an experimental study in Hong Kong, and they concluded that the in-service training program which was applied to teachers improved their self-efficacy perceptions towards inclusive education.

In our study, the professional development competencies of teachers for inclusion didn't differ according to gender, and it was concluded that all teachers, male and female, had the same level of competency. Sahabaz and Kalay (2010) found out that gender didn't make any significant difference in pre-school teacher candidates' efficacy towards inclusion. Contrary to these research findings, in some research results (Moshtaghi \& Fathi, 2017; Toy \& 
Duru, 2016; Yavuz, 2018), there was a significant difference in self-efficacy of teachers working in inclusive classrooms in favor of female teachers.

The status of receiving education for inclusion is an important factor that determines the professional development competencies of teachers for inclusion. Teachers who receive training on this subject find themselves more competent than teachers who don't. In other studies, conducted in the field, it has been determined that teachers who receive in-service special education have a positive effect on their sense of efficacy towards inclusion (Camadan, 2012; Dolapci, 2013; Temel, 2000).

Bandura states that the formation of self-efficacy belief stems from individual experiences. Therefore, more experienced teachers are expected to have high self-efficacy beliefs (Bandura, 1997). However, contrary to expectations, there was no significant difference in the self-efficacy of teachers working in the inclusive class according to the seniority variable of our study. There are also studies that have similar results with the findings of seniority change in our research (Toy \& Duru, 2016; Yorganci \& Bozgeyikli, 2016). This finding of the study is thought to be due to the fact that both inclusive education has been given in special education courses at the university level in recent years and that inclusive students have been placed in classrooms in recent years. Accordingly, it can be thought that the knowledge of newly appointed teachers and the experiences of senior teachers create a similar result.

The qualitative findings of the study consist of advice given by teachers for prospective teachers about inclusive practices. The questions directed to the teachers were grouped under the codes which include classroom adaptations, social development adaptations, parental adaptations, IEP adaptations and adaptations for students with normal development. Teachers' advice about classroom adaptations revealed the themes of professional development and special education content knowledge. Accordingly, teachers expressed their opinions about classroom arrangements, cooperation, content knowledge education, classroom adaptations, exam adaptations and material adaptations. In addition to these views, they also made recommendations to receive training for personal and professional development and to cooperate with education specialists inside and outside the school to make these adaptations. The result of the quantitative findings of this study, which teachers feel more competent about inclusion, is also coincide with the result of teachers' advice for prospective teachers about education. When we look at the advice given by the teachers about the socialization of the inclusive students, they are grouped under two themes as the arrangements for the students about the socialization of them and the cooperation for the staff. Socialization of inclusive students is possible firstly with the common sense and cooperation of staff in the school. After the condition of cooperation with staff is provided, teacher can support the socialization of inclusive student in classroom by giving various tasks in lessons. As stated in the literature (Mastropieri \& Scruggs, 2014), many steps of socialization can be carried out by giving different responsibilities to inclusive students and students with normal development in various activities outside the classroom and peer education.

Another finding we have obtained because of the research consists of the advice given by teachers to prospective teachers about families. The suggestions given by the teachers under this topic were gathered under the theme of parent education. This theme consists of the category of informing the parents of the inclusive students and the families of the students with normal development, which consists of classroom arrangements and student information, and the category of enabling the family, which is an integral part of the education process, and giving responsibility to the families when necessary. This finding is like the results of the research which state that families should be educated in the education of students with special needs (Dogan, 2015; Keceli-Kaysili, 2008).

IEP, which is one of the main conditions for providing education in special education, is also among the advice given by teachers to prospective teachers. These advice of teachers consist of the categories of teachers' IEP preparation, implementation and evaluation (Sari \& Marrow, 2016). Under these categories, the issue that teachers complain mostly about is that they don't have enough knowledge about IEP, so these categories consist of their advice to receive education about IEP. Studies in the field of IEP show that teachers' deficiencies in all stages of IEP 
preparation, implementation, and evaluation cause inadequacies in teamwork. It is stated that it is very important that the student's development process is evaluated by the whole team and that all team members support each other and work in cooperation in this direction (Clark, 2000; İlik, 2017; Ozyurek, 2006). Another suggestion of the teachers about IEP to prospective teachers is that they should try to determine the current performance level of the students, by stating that it is the main condition of preparing a qualified program. In similar studies, it has been determined that teachers have problems in determining the performance of their students and transforming them into written documents (DeBettencourt \& Howard, 2007; İlik, 2017; Werts, Culatta, \& Tompkins, 2007).

As it is known, inclusive education affects not only the inclusive student, but also other normally developing students in this student's class. Accordingly, it was investigated how they made suggestions to the teachers about the students with normal development, and the information given by the teachers on this subject was collected in three categories. They made recommendations about informing the students with normal development about the inclusive student and inclusion, supporting them in terms of education, training and behavior, and bringing them together in common activities. As stated in the literature, informing and interacting are effective in changing attitudes towards individuals with special needs (Ozyurek, 2006). It can be said that the advice of teachers for informing and interacting with the prospective teachers are adaptations aimed at integrating the students. When the qualitative and quantitative findings are handled together, a connection between the teachers working in inclusive classrooms feel themselves moderately competent about inclusion and they don't receive sufficient training on inclusion is established. In this context, it is seen that teachers provide arrangements in inclusive classrooms with their own efforts. Accordingly, the fact that teachers often emphasize cooperation and education shows that they are easy-going and open to improvement. In addition, it is seen that the advice of teachers for prospective teachers are in accordance with the content of the scale used in this research. In this study, the advice of teachers working in inclusive practices for prospective teachers were carefully examined by the researchers and it was seen that this research is important in terms of providing the researchers who conduct the Special Education and Inclusion courses with the opportunity to pay attention in the lessons and to improve the course content they offer to the prospective teachers. In addition, as a result of the examination and evaluation of the results of the research by the academicians who conduct special education and inclusion courses at universities, it can provide introductory information to increase the success of prospective teachers in the future of inclusive practices.

\section{CONCLUSION AND SUGGESTION}

Consequently, the professional development competencies of the teachers participating in the research about inclusion were found to be moderate. While it was determined that the professional development competencies of the teachers about inclusion didn't differ according to their genders, it was concluded that the competencies of the teachers who received education differed according to their educational status about inclusion. It has been observed that there is no significant difference in professional development competencies related to inclusion according to teachers' age, seniority, branch, and types of disabilities of the disabled students in their classes. The results of the study that the advice of teachers participating in the research about inclusion for prospective teachers focused on the themes of professional development, special education content knowledge, regulations for students, cooperation with staff, parent education, IEP education and integration adaptations. According to the results which were obtained from this research, teachers' professional development competencies related to inclusion can be investigated in terms of different variables. Additionally, further studies can be conducted in which the advice of teachers about inclusion for prospective teachers can be investigated according to teachers' own branches.

Funding: This study received no specific financial support.

Competing Interests: The authors declare that they have no competing interests.

Acknowledgement: Both authors contributed equally to the conception and design of the study. 


\section{REFERANCES}

Ahsan, T. V., \& Sharma, U. (2018). Pre-service teachers' attitudes towards inclusion of students with high support needs in regular classrooms in Bangladesh. British Journal of Special Education, 45(1), 81-97. Available at: https://doi.org/10.1111/14678578.12211.

Akalin, S., Demir, S., Sucuoglu, B., Bakkaloglu, H., \& Iscen, F. (2014). The needs of inclusive preschool teachers about inclusive practices. Eurasian Journal of Educational Research, 14(54), 39-60. Available at: https://doi.org/10.14689/ejer.2014.54.3.

Akcamete, G., Kis, A., \& Gurgur, H. (2009). Inclusion model development project for students with special needs. Ankara University Scientific Research Project Final Report. 01.03.2009.

Altun, T., \& Gulben, A. (2009). Evaluation of applications and problems encountered in the education of children with special needs in preschool in terms of teachers' views. Selcuk University Ahmet Kelesoglu Journal of Education Faculty, 28, 253-272.

Bagci, N., \& Simsek, S. (2000). An overview of in-service training activities for National Education personnel. National Education Journal, 146, 9-12.

Bandura, A. (1997). Self-efficacy: The exercise of control. New York: Freeman W.H.

Battal, I. (2007). Evaluation of the competencies of classroom teachers and branch teachers regarding inclusive education. Unpublished Master's Thesis, Afyonkarahisar Kocatepe University, Institute of Social Sciences, Afyon.

Batu, E. S. (2010). Factors for the success of early childhood inclusion ve related studies. International Journal of Early Childhood Special Education, 2(1), 57-71.

Batu, E. S., Odluyurt, S., Alagozoglu, E., Cattik, M., \& Sahin, S. (2017). Determining the opinions of preschool teachers. Ankara University Faculty of Educational Sciences Journal of Special Education, 18(3), 401-420.

Begeny, J., \& Martens, B. (2007). Inclusionary education in Italy: A literature review and call for more. Empirical Research Remedial and Special Education, 28(80), 80-94. Available at: https://doi.org/10.1177/07419325070280020701.

Bozarslan, B., \& Batu, E. S. (2014). Opinions and suggestions of educators working in private kindergartens about inclusion in preschool period. Abant İzet Baysal University Journal of Education Faculty, 14(2), 86-108.

Camadan, F. (2012). Determination of self-efficacy of primary school teachers and primary school teacher candidates about inclusive education and preparation of diapers. Electronic Journal of Social Sciences, 11(39), 128-138.

Chao, C. N. G., Forlin, C., \& Ho, F. C. (2016). Improving teaching self-efficacy for teachers in inclusive classrooms in Hong Kong. International Journal of Inclusive Education, 2O(11), 1142-1154. Available at: https://doi.org/10.1080/13603116.2016.1155663.

Clark, S. G. (2000). The IEP process as a tool for collaboration. Teaching Exceptional Children, 33(2), 56-66.

Crane-Mitchel, L., \& Hedge, A. V. (2007). Belief and practices of in-service preschool teachers in inclusive settings: Implications for personnel preparation. Journal of Early Childhood Teacher Education, 28, 353-366. Available at: https://doi.org/10.1080/10901020701686617.

Cresswell, J. W. (2013). Qualitative inquiry and research design: Choosing among five approaches (3rd ed.). Thousand Oaks, CA: SAGE.

DeBettencourt, L. U., \& Howard, L. A. (2007). The effective special education teacher: A practical guide for success. Upper Saddle River, NJ: Pearson Education.

Diken, İ. H. (2006). Preservice teachers' efficacy and opinions toward inclusion of students with mental retardation. Eurasian Journal of Educational Research, 23, 72-81.

Dogan, M. (2015). Children with disabilities, family and family education: Conceptual and practical developments. Abant Izzet Baysal University Journal of the Faculty of Education, 15, 111-127.

Dolapci, S. (2013). Self-efficacy perceptions of pre-service teachers and their perspectives on inclusive education. Master Thesis. Dokuz Eylul University, Graduate School of Educational Sciences, Department of Special Education, Special Education Program, İzmir, Turkey.

Farrell, P. (2000). The impact of research on developments in inclusive education. International Journal of Inclusive Education, 4(2), 153162. Available at: https://doi.org/10.1080/136031100284867.

Forlin, C., \& Kuen-Fung, S. K. (2017). In-service teacher training for inclusion: Best practice models for Professional learning. George Noblit (Ed.) (pp. 1-26): Oxford Research Encyclopedia of Education. 
Gok, G., \& Erbas, D. (2011). Opinions and suggestions of preschool education teachers about inclusive education. International Journal of EarlyChildhood Special Education, 3(1), 66-87.

Greene, J. C. (2007). Mixed methods in social inquiry. San Francisco: Wiley.

İlik, S. S. (2017). Examination and evaluation of individualized education programs prepared for intellectual disability students. International Journal of Human Sciences, 14(4), 4898-4909.

Kale, M., Dikici Sigirtmac, A. İ. N., \& Abbak, B. S. (2016). Examination of pre-school teachers' views on inclusive education practices. International Journal of Early Childhood Education Studies, 1(2), 38-48.

Kaner, S. (2010). Psychometric properties of the revised parental social support scale. Education and Science, 157(36), 15-29.

Karaca, M. A. (2018). The effect of inclusive education program on teachers' professional competencies in inclusive practices. Unpublished Master's Thesis Necmettin Erbakan University, Institute of Educational Sciences, Department of Special Education, Konya.

Karagiannis, A., Stainback, W., \& Stainback, S. (1996). Rationale for inclusive schooling. In S. B. Stainback \& W. C. Stainback (Eds.), Inclusion: A guide for educators (pp. 3-15): Paul H Brookes Publishing.

Kardes, S., \& Taskin, N. (2020). Preschool teacher candidates' perceptions of special needs children. Gazi University Journal of Gazi Education Faculty, 4O(1), 51-73. Available at: https://doi.org/10.17152/gefad.658084.

Keceli-Kaysili, B. (2008). Family participation in increasing academic success. Ankara University Faculty of Educational Sciences Journal of Special Education, 9(1), 69-83.

Kiel, E., Braun, A., Muckenthaler, M., Heimlich, U., \& Weiss, S. (2019). Selfefficacy of teachers in inclusive classes. How do teachers with different self-efficacy beliefs differ in implementing inclusion? European Journal of Special Needs Education. Available at: https://doi.org/10.1080/08856257.2019.1683685.

Kucuk Dogaroglu, T., \& S., B. D. S. (2015). Examination of the views of preschool teachers who have mainstreaming students in their classrooms on mainstreaming education and early intervention. Hacettepe University Faculty of Health Sciences Journal, 1(2), $460-473$.

Majoko, T. (2018). Zimbabwean general education preschool teacher needs in inclusion. SAGE Open, 8(2), 2158244018777568. Available at: https://doi.org/10.1177/2158244018777568.

Mastropieri, M. A., \& Scruggs, T. E. (2004). The inclusive classroom strategies for effective instruction (2nd ed.). New Jersey: Upper Saddle River, Colombus Ohio.

Mastropieri, M. A., \& Scruggs, T. E. (2014). The inclusive classroom: Strategies for effective differentiated instruction (5th ed.). Upper Saddle River, NJ: Pearson Education.

McGregor, G., Halverson, A., Fisher, I. P., Bhaermen, B., \& Salisbury, C. (1998). Professional development for “all” personnel in inclusive schools [Issue Brief,(3) 3.]. Pittsburgh, PA: Allegheny University of the Health Sciences, The Consortium on Inclusive School Practices.

MEB. (2017). National education statistics formal education. http://sgb.meb.gov.tr/meb_iys_dosyalar/2017_09/08151328_meb_istatistikleri_orgun_egitim 2016_2017.pdf.

Mertkan, S. (2015). Mixed research design. Ankara: Pegem Academy Publishing.

Metin, N. (2018). Teacher in preschool inclusion class. Journal of Early Childhood Studies, 2(2), 428-439.

Moshtaghi, S., \& Fathi, N. (2017). Relationship between the components of interpersonal self-efficacy and computer self-efficacy among teachers in dezful city. Interdiscip J Virtual Learn Med Sci, 8(1), 1-7. Available at: https://doi.org/10.5812/ijvlms.11497.

Mulholland, S., \& Cumming, M. T. (2016). Investigating teacher attitudes of disability using a non-traditional theoretical framework of attitude. International Journal of Education and Research, 80, 93-100. Available at: https://doi.org/10.1016/j.ijer.2016.10.001.

Odom, S. L. (2000). Preschool inclusion: What we know and where we go from here. Topics in Early Childhood Special Education, 20(1), 20-27. Available at: https://doi.org/10.1177/027112140002000104.

Ozyurek, M. (2006). Changing attitudes towards people with disabilities. Ankara: Coke Publishing.

Sahabaz, U., \& Kalay, G. (2010). Determining the views of pre-school education teacher candidates about inclusion. Mehmet Akif Ersoy University Journal of the Faculty of Education, O(19), 116-135. 
Saloviita, T. (2020). Teacher attitudes towards the inclusion of students with support needs. Journal of Research and Special Education Needs, 20, 64-73. Available at: https://doi.org/10.1111/1471-3802.12466.

Sari, H., Celikoz, N., \& Seçer, Z. (2009). An analysis of pre-school teachers' and student teachers' attitudes to inclusion and their selfefficacy. International Journal of Special Education, 24(3), 29-44.

Sari, H., \& Marrow, S. S. (2016). Individualized education plan. Ankara: Egiten Book.

Sazak Pinar, E. (2014). Identification of inclusive education classroom teachers views and needs regarding in-service training on special education in Turkey. Educational Research and Reviews, 9(20), 1097-1108.

Soodak, L. C., \& Podell, D. M. (1993). Teacher efficacy and student problem as factors in special education referral. The Journal of Special Education, 27(1), 66-81. Available at: https://doi.org/10.1177/002246699302700105.

Sucuoglu, B., \& Akalin, S. (2010). An alternative view to mainstreaming classrooms: Examination of instructional features with environmental behavioral assessment. Ankara University Faculty of Educational Sciences Journal of Special Education, 11(1), 1937. Available at: https://doi.org/10.1501/Ozlegt_0000000144.

Taymaz, A., H., Sunay, Y., \& Aytac, T. (1997). Meeting to ensure coordination in in-service training. Journal of National Education, 133, $13-17$.

Temel, Z. F. (2000). Preschool educators' views on the integration of the disabled. Hacettepe University Journal of the Faculty of Education, $18,148-155$.

Toy, S. N., \& Duru, S. (2016). Comparison of classroom teachers' teacher self-efficacy and their efficacy beliefs about inclusive education. Aegean Journal of Education, 17(1), 146-173.

Tufan, M., \& Ylldırım, Y. (2013). Examination of preschool teachers' knowledge levels about the concepts of early intervention and inclusion and their instructional adaptations for children with special needs. Cumhuriyet International Journal of EducationCIJE, 2(4), 1-13.

Unal, F., \& Saban, A. (2017). Attitudes of teachers towards mainstreaming in classrooms where mainstreaming is practiced. C.U. Journal of Social Sciences Institute, 23(1), 388-405.

Vural Batik, M., \& Firinci Kodaz, A. (2018). The effect of institutional experience on special education self-efficacy perceptions of psychological counselor candidates. Ondokuz Mayis University Journal of the Faculty of Education, 37(1), 209-222.

Werts, M. G., Culatta, R. A., \& Tompkins, J. R. (2007). Fundamentals of special education: What every teacher needs to know. Upper Saddle River, N.J: Pearson/Merrill Prentice Hall.

Yavuz, M. (2018). Investigation of interpersonal self-efficacy beliefs of teachers working in mainstreaming classes in terms of some variables. Kastamonu Journal of Education, 26(6), 2057-2067.

Yikmis, A., \& Bahar, M. (2002). Determining the realization of inclusion skills of teachers working in inclusive classrooms. Abant $\dot{I}_{z z e t}$ Baysal University Journal of Education Faculty, 2(1), 85-95. Available https://dergipark.org.tr/tr/pub/aibuefd/issue/1508/18290.

Yildirim, A., \& Simsek, H. (2006). Qualitative research methods in the social sciences. Ankara: Seckin Publishing.

Yorganci, A., \& Bozgeyikli, H. (2016). Examination of classroom teachers' perceptions of interpersonal self-efficacy and organizational trust. OPUS International Journal of Society Studies, 6(10), 47-79. 